\title{
Characterization and Pathogenicity of a New Anastomosis Subgroup AG-2-3 of Rhizoctonia solani Kühn Isolated from Leaves of Soybean
}

\author{
Shigeo NAITO* and Seiji KANEMATSU*
}

\begin{abstract}
During July to August in 1992, a unusual foliar blight disease was observed on soybean plants intercropped between rows of winter wheat in an upland field converted from a paddy field at Tohoku National Agricultural Experiment Station in Morioka, northern part of Japan. The symptoms appeared as primary lesions consisting of small, circular necrotic spots, 1-mm or less than 1-mm in diameter, followed by secondary lesions showing circular to irregularly-shaped and large-sized areas of necrosis around the primary lesions under humid conditions. All the isolates of Rhizoctonia solani Kühn consistently recovered from leaves with the primary and secondary lesions (hereinafter referred to as leaf spot isolates) formed anastomoses in a high frequency $(>75 \%)$ with the tester isolates of the anastomosis subgroup AG-2-1 but in a low frequency $(<16 \%)$ with those of the AG-2-2 IIIB and IV and anastomosis group AG-BI. Among the 66 leaf spot isolates, 64 were auxotrophic for thiamine, whereas the isolates of the AG-2-1 were autotrophic for thiamine. The remaining 2 isolates could not grow even in the presence of thiamine. Culture appearance and optimum growth temperature of the leaf spot isolates were similar to those of the AG-2-1 rather than to those of the AG-2-2 IIIB and IV subgroup. Inoculation tests revealed that the leaf spot isolates were highly pathogenic to soybean, adzuki bean and kidney bean and caused severe pre-emergence and post-emergence damping-off, but were not pathogenic to rape and radish. The isolates caused foliar blight on soybean. These results indicated that most of the leaf spot isolates of AG-2 from soybean did not fit to either the AG-2-1 or AG-2-2 subgroup. Hence, we assigned these isolates to a new subgroup 3 in AG-2 (designated as AG-2-3).
\end{abstract}

(Received June 13, 1993)

Key words : soybean, foliar blight, Rhizoctonia solani, anastomosis group, pathogenicity.

\section{INTRODUCTION}

Soybean (Glycine max (L.) Merr.) was a popular rotational crop in upland fields converted from paddy fields during the last decade, in Japan. Recently, after paddy rice was harvested, the three-crop system consisting of soybean - winter wheat-intercropped soybean in a 2-yr period has been developed as a new farming technique for reorganizing paddy field utilization in the Tohoku District, northern part of Japan. From July to August in 1991, a unusual foliar blight disease caused by Rhizoctonia solani Kühn (teleomorph $=$ Thantephorus cucumeris (Frank) Donk) was observed on soybean plants grown in a field between rows of winter wheat at the Tohoku National Agricultural Experiment Station in Morioka. In 1992 and 1993, the disease was detected in fields with continuous or rotational cropping of soybean at our station and in other locations in Iwate, Miyagi and Akita Prefectures. The disease occurred before and after wheat plants were harvested.

\footnotetext{
* Tohoku National Agricultural Experiment Station, Akahira 4, Shimo-Kuriyagawa, Morioka 020-01, Japan 東 北農業試験場
} 
To date, Rhizoctonia foliar blight of soybean has been divided into two types on the basis of symptoms: aerial blight caused by anastomosis group AG-1 IA and web blight caused by AG-1 IB ${ }^{3,22,23)}$ of $R$. solani. The symptoms of the new foliar blight disease are quite different from those of aerial blight and web blight of soybean caused by hyphal infection ${ }^{1,22)}$. In a preliminary report ${ }^{9}$, the authors stated that the new foliar blight of soybean may be caused by basidiospores of the teleomorph of $R$. solani.

$R$. solani AG-1 IA and AG-1 IB from foliar blight of soybean have been reported in many countries $^{3,19,22,23)}$. Most isolates of $R$. solani consistently obtained from leaves with symptoms of the new foliar blight belonged to AG-2, but not to either the subgroup AG-2-1 or AG-2-2 on the basis of the anastomosis frequency and thiamine requirement. Hence, some attempts were made to idientify the anastomosis subgroup of the isolates of $R$. solani from leaves with primary or secondary lesions on soybean. Preliminary results have been published ${ }^{9,10)}$.

\section{MATERIALS AND METHODS}

Isolation. Blighted leaves of soybean were collected from 16 fields in Iwate, Aomori, Akita, and Miyagi Prefectures during late June through early October from 1991 to 1993. Surface-disinfected portions of diseased leaf tissues were placed on $2 \%$ water agar (WA) adjusted to $\mathrm{pH} 5.0$ with lactic acid and incubated at $25^{\circ} \mathrm{C}$ for $48 \mathrm{hr}$. Hyphal tips of $R$. solani emerging from the diseased tissues were transferred to potato-sucrose agar (PSA) for axenic culture. Fungal characteristics described by Parmeter and Whitney ${ }^{15)}$ were used to assign the isolates to species of $R$. solani. Since all the isolates from the leaves showing web blight symptoms fell into the AG-1 IB (Table 1), only isolates from the blighted leaves with primary and secondary lesions (hereinafter designated as leaf spot isolates) were used to determine the anastomosis group and pathogenicity. Representative leaf spot isolates from soybean was shown in Table 3.

Anastomosis grouping. Leaf spot isolates were tested for their ability to anastomose with each of the tester isolates belonging to the 8 AGs, AG-1 through AG-7 and AG-BI groups. Dual culture was carried out by placing two 5 -mm-diameter disks 2 to $3 \mathrm{~cm}$ apart on WA in a 9 -cm-diameter petri dish at $23^{\circ} \mathrm{C}$ under dark conditions until advancing hyphae from opposite sides made contact and properly overlapped, usually within 24 to $48 \mathrm{hr}$. The area upon which branch hyphae overlapped was excised, placed on a glass slide, stained with $0.5 \%$ cotton blue in lactophenol, and observed microscopically $(400 \times)$ for hyphal anastomosis. About 100 observations were made per isolate.

Thiamine requirement. To determine the thiamine requirement of the leaf spot isolates from soybean, two culture methods were used: first, among the 64 leaf spot isolates, 7 were grown in a $100 \mathrm{ml}$ conical flask containing $30 \mathrm{ml}$ of glucose asparagine medium (GA) with or without $10^{-5} \mathrm{M}$ thiamine hydrochloride; second, all the isolates were grown on an agar plate containing GA with or without thiamine in a 9-cm-diameter petri dish, according to the procedure described by Ogoshi ${ }^{14)}$. A $5-\mathrm{mm}$ mycelial disk from the growing edge of a colony on PSA was transferred to a thin layer of WA in a petri dish, incubated at $25^{\circ} \mathrm{C}$ for 5 days, then a 5 -mm mycelial disk from cultures on WA was gently floated on the liquid medium in a flask or placed on the agar medium in a petri dish. Mycelial dry weight determinations were made after 10-day incubation at $25^{\circ} \mathrm{C}$ in the dark with 5 replications. Each experiment included 2 tester isolates from the AG-2-1, AG-2-2 III A and IV subgroups as controls.

Culture characteristics. Cultures were grown on potato-dextrose agar (PDA) (Difco) or PSA at 23 or $25^{\circ} \mathrm{C}$ in the dark. Observations on culture appearance, pigmentation, sclerotia and zonation were made over a 2 -week period. Hyphal diameter was determined by measuring the size of the runner hyphae on WA after a 4 -day incubation period at $25^{\circ} \mathrm{C}$.

Staining of nuclei. A 5-mm mycelial disk from the growing edge of a colony on PSA was transferred to the center of a cellophane membrane resting on WA in $9-\mathrm{cm}$ petri dishes and incubated at $25^{\circ} \mathrm{C}$ for 2 or 3 days. Mature hyphae on a piece of the excised cellophane membrane $(1 \times 2 \mathrm{~cm})$ were fixed in a 3:1 mixture of ethanol: glacial acetic acid for $10 \mathrm{~min}$, hydrolyzed with $1 \mathrm{~N}-\mathrm{HCl}$ at $60^{\circ} \mathrm{C}$, then stained with $1 \%$ carmine in $45 \%$ acetic acid ${ }^{12)}$ for microscopical observation $(400 \times$ or $1,000 \times)$ of nuclei in a second cell from a hyphal tip. Fifty observations were made per isolate. 
Mycelial growth. A 5-mm mycelial disk taken from an actively growing colony on PSA was placed in the center of PDA (Difco) and incubated at the temperatures of 5, 10, 15, 20, 23, 25, 27, 30, 33, and $35^{\circ} \mathrm{C}$. Hyphal growth in 4 replicated cultures at each temperature was examined daily until the colony reached the edge of the 9 -cm-diameter petri dish. One isolate from each subgroup representing $\Lambda$ G-2-1, AG-2-2 III B and IV was used as control.

Pathogenicity test. Five isolates from leaf spots with primary and secondary lesions were tested for pathogenicity to seedlings of soybean (Glycine max (L.) Merr. cv. Waseshiroge), adzuki bean (Phaseolus angularis L. cv. Dainagon), kidney bean (Phaseolus vulgaris L. cv. Taishokintoki), pea (Pisum sativum L. cv. Kinuzaya), radish (Raphanus sativus L. cv. Risou), wheat (Triticum aestivum L. cv. Nanbukomugi), sugarbeet (Beta vulgaris L. cv. Mono Ace), spinach (Spinacia oleracea L. cv. Kyanion), rape (Brassica rapa L. cv. Kizakino) and potato (Solanum tuberosum L. cv. Danshaku), and to leaves of soybean (Glycine max (L.) Merr. cv. Fukunagaha). They were grown in a 15-cm-diameter pot with non-sterilized nursery soil (Engei Baido, Kureha Co.). Inoculum was prepared by growing isolates in flasks containing autoclaved barley grains ${ }^{11)}$ at $25^{\circ} \mathrm{C}$ for 2 weeks. Two grams of inoculum per pot were mixed with the surface soil, $2-4 \mathrm{~cm}$ deep, at the sowing time. The inoculated plants were placed on the bench in a glass house kept at $20^{\circ} \mathrm{C}$. After one month, pre- and post-emergence damping-off of the seedlings was examined. To determine the pathogenicity to soybean leaves, the culture grown on the autoclaved soybean leaf cuttings $(1 \times 1 \mathrm{~cm})$ was placed in the center of the adaxial side of the leaf, then covered with a piece of moistened cotton. The inoculated plants were kept in a moist chamber with a humidifier connected to an electric timer at $15-\mathrm{min} / \mathrm{hr}$ in the daytime and $15-\mathrm{min} / 3 \mathrm{hr}$ in the night. After 4-day incubation at $20-25^{\circ} \mathrm{C}$, the disease severity was individually rated on a scale of $0-5$, where $0=$ healthy, $1=$ slightly infected, $2=1 / 4$ infected, $3=1 / 2$ infected, $4=3 / 4$ infected, and $5=$ dead leaf. For the reisolation of the fungus, the diseased roots or leaves were cut into small segments $(5 \times 5 \mathrm{~mm})$, which were washed in running tap water and surface-disinfected for $1 \mathrm{~min}$ in $1 \% \mathrm{NaOCl}$, plated onto WA (pH 5), and incubated at $25^{\circ} \mathrm{C}$.

\section{RESULTS}

\section{Symptoms}

The symptoms of the new foliar blight of soybean appeared as primary lesions consisting of circular necrotic spots, $1-\mathrm{mm}$ or less than 1-mm in diameter, and as secondary lesions showing circular to irregularly-shaped and large-sized areas of necrosis around the primary lesions under humid conditions (Fig. 1). The disease was mostly developed on young or middle-aged leaves. The powdery-white hymenia were sometimes observed on the ventral side of diseased leaves.

\section{Anastomosis group}

Twelve isolates from the leaves of soybean showing web blight symptoms were easily assigned to the AG-1 IB of $R$. solani (Table 1). Among the 66 leaf spot isolates from primary lesions and secondary
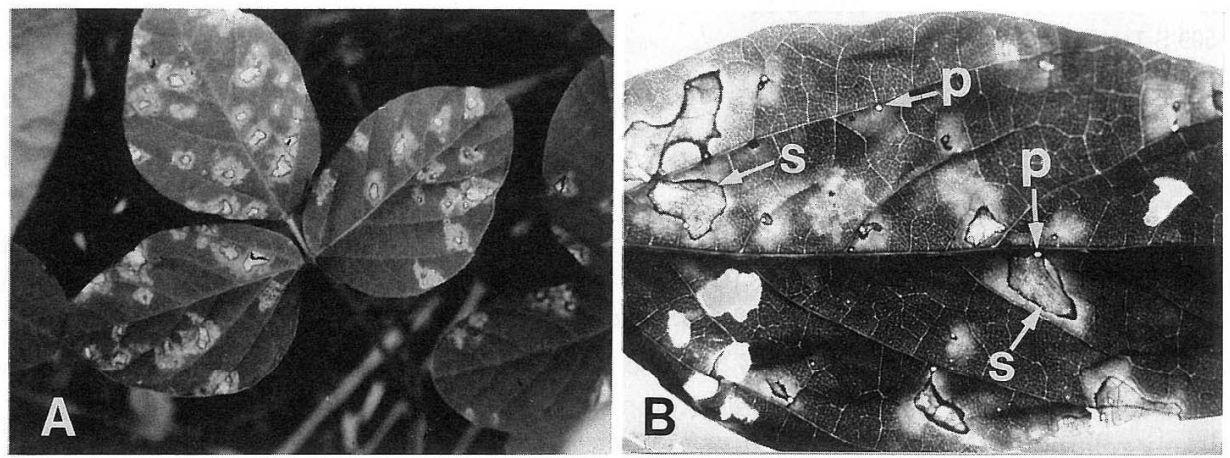

Fig. 1. Foliar blight of soybean caused by new anastomosis subgroup AG-2-3 of Rhizoctonia solani. A: leaf spot on soybean cultivar "Kosuzu" in a field, B: primary lesion (p) and secondary lesion (s) in a field. 
Table 1. Anastomosis groups of isolates of Rhizoctonia solani obtained from leaves of soybean in Tohoku District

\begin{tabular}{|c|c|c|c|c|c|c|}
\hline \multirow{2}{*}{ Year } & \multirow{2}{*}{ Location } & \multirow{2}{*}{$\begin{array}{c}\text { Type of } \\
\text { symptom }^{\text {a) }}\end{array}$} & \multirow{2}{*}{$\begin{array}{l}\text { No. of } \\
\text { isolates }\end{array}$} & \multicolumn{3}{|c|}{ No. of isolates in each anastomosis group } \\
\hline & & & & AG-1 IB & New group & Other's AG \\
\hline \multirow[t]{6}{*}{1991} & Morioka, Iwate A & Leaf spot, $\mathrm{p}$ & 16 & 0 & 16 & 0 \\
\hline & do , Iwate B & do, $\mathrm{s}$ & 11 & 0 & 11 & 0 \\
\hline & Natori, Miyagi & $\mathrm{s}$ & 2 & 0 & 2 & 0 \\
\hline & Ishikawa, Fukushima & Web blight & 3 & 3 & 0 & 0 \\
\hline & Towada, Aomori & do & 3 & 3 & 0 & 0 \\
\hline & Gonohe, Aomori & do & 2 & 2 & 0 & 0 \\
\hline 1992 & Morioka, Iwate & Leaf spot, p & 14 & 0 & 14 & 0 \\
\hline \multirow[t]{9}{*}{1993} & Morioka, Iwate & Leaf spot, p & 6 & 0 & 6 & 0 \\
\hline & Shizukuishi, Iwate A & do, $\mathrm{p}$ & 2 & 0 & 2 & 0 \\
\hline & do , Iwate B & $\mathrm{p}$ & 2 & 0 & 2 & 0 \\
\hline & Nishikimura, Akita & $\mathrm{s}$ & 2 & 0 & 0 & $2^{\text {b) }}$ \\
\hline & Kurikoma, Miyagi & $\mathrm{p}$ & 4 & 0 & 4 & 0 \\
\hline & do , Miyagi & $\mathrm{s}$ & 6 & 0 & 6 & 0 \\
\hline & Uguisuzawa, Miyagi &, $\mathrm{p}$ & 1 & 0 & 1 & 0 \\
\hline & Takizawa, Iwate & Web blight & 2 & 2 & 0 & 0 \\
\hline & Tamayama, Iwate & do & 2 & 2 & 0 & 0 \\
\hline
\end{tabular}

a) Leaf spot with primary lesion (p), 1-mm in size, and with secondary lesion (s) developed around the primary lesion.

b) Isolates freely anastomosed with those of the AG-2-1 subgroup, but could not grow on glucose asparagine medium with thiamine. They grew well on $\mathrm{GA}+$ thiamine- $\mathrm{HCl}+0.5 \%$ yeast extract.

Table 2. Hyphal anastomosis frequency between leaf spot isolates from soybean and tester isolates in AG-2-1, AG-2-2 and AG-BI of Rhizoctonia solani ${ }^{\text {a) }}$

\begin{tabular}{|c|c|c|c|c|}
\hline \multirow{2}{*}{ Isolate } & \multirow{2}{*}{ Anastomosis group } & \multicolumn{3}{|c|}{ Hyphal fusion (\%) with leaf spot isolate from soybean } \\
\hline & & $\mathrm{R}-1$ & $\mathrm{R}-4$ & $\mathrm{R}-8$ \\
\hline \multicolumn{5}{|c|}{ Leaf spot isolate from soybean } \\
\hline $\mathrm{R}-1$ & New group & 92 & 89 & 92 \\
\hline $\mathrm{R}-4$ & do & - & 88 & 91 \\
\hline $\mathrm{R}-8$ & do & - & - & 93 \\
\hline \multicolumn{5}{|c|}{ Tester isolate of subgroup in AG-2 } \\
\hline SSa-1 & AG-2-1 & 75 & 81 & 84 \\
\hline MAFF-305203 & do & 81 & 82 & 70 \\
\hline C-96 & AG-2-2 IIIB & 7 & 10 & - \\
\hline C-116 & do & 5 & 2 & - \\
\hline OPR1-1 & do & 5 & 4 & 2 \\
\hline Pf-28 & AG-2-2 IV & 7 & 6 & 12 \\
\hline Rh-509-S-1 & do & 5 & 7 & 3 \\
\hline TE2-4 & AG-BI & 16 & 9 & 4 \\
\hline
\end{tabular}

a) About 100 overlapped hyphae in dual culture were microscopically observed for the determination of anastomosis group.

lesions, representative isolates R-1, R-4 and R-8 (leaf spot isolates from soybean) displayed anastomoses in a high frequency $(>75 \%)$ with tester isolates of AG-2-1, but in a low frequency $(<16 \%)$ with the AG-2-2 IIIB and IV, and AG-BI isolates (Table 2). No leaf spot isolate formed anastomoses with any of the isolates of the AG-1, AG-3, AG-4, AG-5, AG-6, and AG-7 groups. The remaining 63 isolates freely anastomosed with AG-2-1. Based on the anastomosis frequency between isolates, the leaf spot isolates were closely related to AG-2-1.

\section{Thiamine requirement}

When 7 representative leaf spot isolates from soybean were grown in liquid GA with or without 
Table 3. Thiamine requirement of leaf spot isolates of Rhizoctonia solani obtained from soybean

\begin{tabular}{|c|c|c|c|c|c|}
\hline \multirow[b]{2}{*}{ Isolate } & \multirow[b]{2}{*}{$\begin{array}{l}\text { Anastomosis } \\
\text { group }\end{array}$} & \multirow[b]{2}{*}{$\begin{array}{l}\text { Source of } \\
\text { isolates }\end{array}$} & \multicolumn{2}{|c|}{ "Mycelial dry weight (mg)/flask } & \multirow[b]{2}{*}{$\mathrm{B} / \mathrm{A}$} \\
\hline & & & $\begin{array}{c}\text { Basal } \\
\text { medium }(\mathrm{A})^{\mathrm{a})}\end{array}$ & $\begin{array}{l}\text { Basal medium }+ \\
\text { Thiamine }(\mathrm{B})^{\mathrm{b})}\end{array}$ & \\
\hline \multicolumn{6}{|c|}{ Leaf spot isolate from soybean } \\
\hline $\mathrm{R}-1$ & New group & Soybean, leaf & 5.4 & 190.3 & 35.2 \\
\hline R-3 & do & do , leaf & 5.5 & 145.6 & 26.5 \\
\hline R-4 & do & do , leaf & 4.3 & 77.6 & 18.1 \\
\hline R-6 & do & do , leaf & 4.7 & 190.8 & 40.6 \\
\hline $\mathrm{R}-8$ & do & do , leaf & 4.3 & 192.9 & 44.9 \\
\hline H5-302 & do & do , leaf & 4.1 & 192.9 & 47.1 \\
\hline H5-323 & do & do , leaf & 4.1 & 95.1 & 23.2 \\
\hline \multicolumn{6}{|c|}{ Tester isolate of subgroup in AG-2 } \\
\hline MAFF-305203 & AG-2-1 & Soil & 33.4 & 52.0 & 1.6 \\
\hline SSa-1 & do & do & 24.1 & 17.1 & 0.7 \\
\hline C-116 & AG-2-2 IIIB & Rush, sheath & 3.3 & 185.5 & 56.2 \\
\hline C-335 & do & do , sheath & 4.0 & 171.1 & 42.8 \\
\hline Pf-28 & AG-2-2 IV & Sugarbeet, root & 4.4 & 190.2 & 43.2 \\
\hline Rh-509-S-1 & do & do, root & 5.4 & 196.2 & 36.3 \\
\hline
\end{tabular}

a) Glucose asparagine medium used by Ogoshi and $\mathrm{Ui}^{14)}$.

b) Concentration: $10^{-5} \mathrm{M}$.
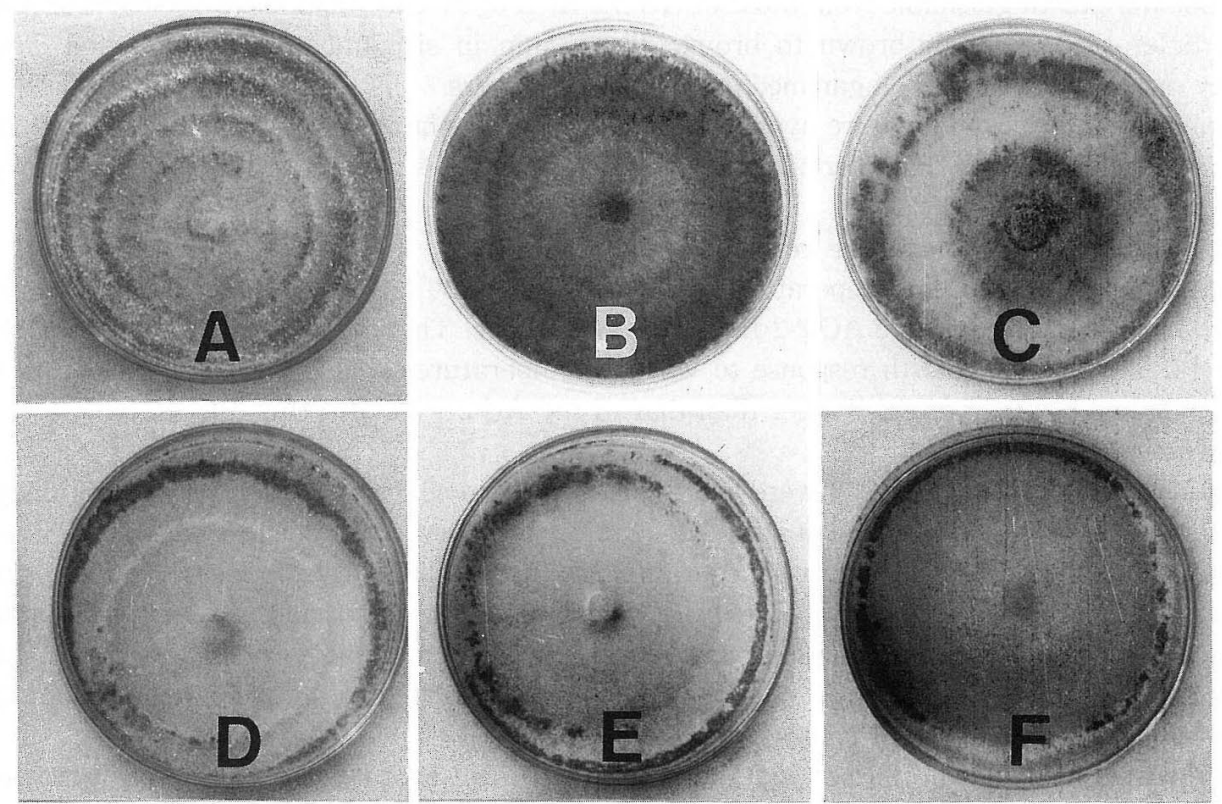

Fig. 2. Culture appearance of isolates in new anastomosis subgroup AG-2-3 of Rhizoctonia solani on PDA. A: isolate of AG-2-1, B: isolate of AG-2-2 IIIA, C: isolate of AG-2-2 IV, D,E and F: isolate of AG-2-3.

thiamine, they were auxotrophic for thiamine and more closely resembled the isolates of AG-2-2 III B or IV which are thiamine-auxotrophic than those of AG-2-1 which are thiamine-autorophic (Table 3). On solid culture, among the 66 isolates from leaf spots 64 were auxotrophic for thiamine. The remaining two isolates could not grow even when thiamine was added to GA, but grew well on GA supplemented with $1 \%$ yeast extract (Table 1 ).

Accordingly, leaf spot isolates that freely anastomosed with tester isolates of AG-2-1 were auxotrophic for thiamine, except for two isolates. 


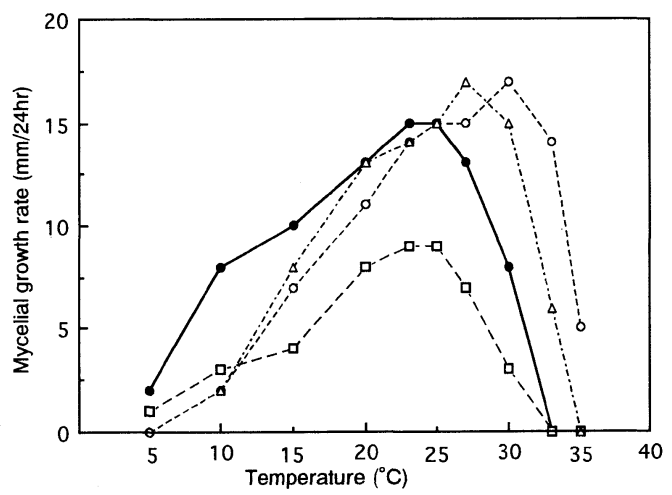

Fig. 3. Mycelial growth rate of leaf spot isolate of Rhizoctonia solani obtained from soybean at various temperatures. $\bigcirc$ : OPR1-1 (AG-2-2, IIIB), $\triangle$ : Rh-509-S-1 (AG-2-2, IV), ๑ : R-1 (new group), $\square$ : MAFF-305203 (AG-2-1).

\section{Culture characteristics}

Leaf spot isolates from soybean were identical with each other in the culture appearance on PDA or PSA. The colonies were whitish at first, and turned light brown and somewhat lightly reddish brown after 2 weeks. Zonation in the form of concentric rings was frequently observed. Mycelia, generally, were appressed to the agar surface. These characteristics were similar to those of the colonies of AG-2-1, but were distinguishable from those of AG-2-2 III B or IV showing a brown to dark-brown color (Fig. 2). Sclerotia were light-brown to brown, 1 to $7-\mathrm{mm}$ in size (mostly 1-3-mm), and developed discretely on the surface of the agar medium in small numbers.

Number of nuclei in the mature hyphal cells of leaf spot isolates ranged from 4 to 11 with a mean number of 8 nuclei per cell. Diameter of runner hyphae of 4 isolates ranged from 7 to $13 \mu \mathrm{m}$ with a mean value of $9.6 \mu \mathrm{m}$.

\section{Mycelial growth-temperature relationships}

Leaf spot isolates grew at temperatures ranging from 5 to $30^{\circ} \mathrm{C}$. The optimum growth temperature was $23^{\circ} \mathrm{C}$, lower than that of the AG-2-2 III B and IV isolates. The linear growth rate was $14-15 \mathrm{~mm} /$ $24 \mathrm{hr}$ on PDA. Mycelial growth response to various temperatures was similar to that of the AG-2-1 isolates, but the growth rate was higher than that of the AG-2-1 isolates (Fig. 3).

\section{Pathogenicity}

Leaf spot isolates from soybean were highly pathogenic to soybean, adzuki bean and kidney bean, causing pre- and post-emergence damping-off, but not pathogenic to radish and rape (Table 4). In contrast, tester isolates of AG-2-1 were highly pathogenic to radish and rape in the Cruciferae as pointed out by other researchers ${ }^{13,19,20)}$. Pathogenicity to wheat plant was mild, and resulted in irregular and brown lesions on the lower sheath without any damage. The tester isolates of both AG-2-2 III B and IV were not pathogenic to wheat plant. The fungi tested were reisolated from the diseased tissues of roots or hypocotyls of each inoculated plant.

When leaves of soybean in a pot were inoculated with leaf spot cultures, blight occurred severely (Table 5), but primary and secondary lesions were not induced. The fungus was recovered from the inoculated leaves.

\section{DISCUSSION}

Rhizoctonia foliar blight of soybean has been divided into two types on the basis of symptoms: aerial blight caused by AG-1 IA and web blight caused by AG-1 IB of $R$. solani ${ }^{3,8,22,23)}$. Unusual foliar blight of soybean, which severely occurred in the field of soybean plants intercropped between rows of winter wheat, induced the formation of primary lesions with a stroma-like body ${ }^{9}$ within the diseased tissue, 1-mm or less than 1-mm in diameter, followed by circular to irregular secondary lesions. The 
Table 4. Pathogenicity of leaf spot isolates of Rhizoctonia solani obtained from soybean ${ }^{\text {a) }}$

\begin{tabular}{|c|c|c|c|c|c|}
\hline \multirow{2}{*}{$\begin{array}{c}\text { Plant } \\
\text { inoculated }\end{array}$} & \multirow{2}{*}{ Isolate } & \multirow{2}{*}{$\begin{array}{l}\text { Anastomosis } \\
\text { group }\end{array}$} & \multirow{2}{*}{ No. of seed } & \multicolumn{2}{|c|}{ Damping-off (\%) } \\
\hline & & & & Pre-emergence & Post-emergence \\
\hline \multicolumn{6}{|l|}{ Experiment $\mathrm{I}^{\mathrm{b})}$} \\
\hline \multirow[t]{6}{*}{ Soybean } & R-4 & (New group) & 25 & 100 & 0 \\
\hline & R-8 & ( do ) & 25 & 100 & 0 \\
\hline & SSa-1 & $(\mathrm{AG}-2-1)$ & 25 & 0 & 60 \\
\hline & OPR1-1 & (AG-2-2, IIIB) & 25 & 0 & 16 \\
\hline & Pf- 28 & $(\mathrm{AG}-2-2, \mathrm{IV})$ & 25 & 92 & 100 \\
\hline & Not inoculated & & 25 & 0 & 0 \\
\hline \multirow[t]{6}{*}{ Radish } & $\mathrm{R}-4$ & (New group) & 50 & 0 & 12 \\
\hline & $\mathrm{R}-8$ & ( do ) & 50 & 0 & 10 \\
\hline & SSa-1 & $(\mathrm{AG}-2-1)$ & 50 & 100 & - \\
\hline & OPR1-1 & (AG2-2, IIIB) & 50 & 0 & 85 \\
\hline & Pf-28 & $(\mathrm{AG}-2-2, \mathrm{IV})$ & 50 & 45 & 85 \\
\hline & Not inoculated & & 50 & 0 & 9 \\
\hline \multirow[t]{6}{*}{ Wheat } & R-4 & (New group) & 75 & 0 & 7 \\
\hline & R-8 & ( do ) & 75 & 5 & 37 \\
\hline & SSa-1 & $(\mathrm{AG}-2-1)$ & 75 & 12 & 17 \\
\hline & OPR1-1 & (AG-2-2, IIIB) & 75 & 0 & 3 \\
\hline & Pf-28 & $(\mathrm{AG}-2-2, \mathrm{IV})$ & 75 & 4 & 0 \\
\hline & Not inoculated & & 75 & 0 & 0 \\
\hline \multirow[t]{6}{*}{ Spinach } & $\mathrm{R}-4$ & (New group) & 50 & 0 & 4 \\
\hline & R-8 & ( do ) & 50 & 5 & 50 \\
\hline & SSa-1 & $(\mathrm{AG}-2-1)$ & 50 & 66 & 60 \\
\hline & OPR1-1 & (AG-2-2, IIIB) & 50 & 0 & 13 \\
\hline & Pf-28 & $(\mathrm{AG}-2-2, \mathrm{IV})$ & 50 & 23 & 62 \\
\hline & Not inoculated & & 50 & 0 & 5 \\
\hline \multicolumn{6}{|l|}{ Experiment $\mathrm{II}^{\mathrm{c})}$} \\
\hline \multirow[t]{6}{*}{ Soybean } & $\mathrm{R}-1$ & (New group) & 50 & 100 & - \\
\hline & $\mathrm{R}-4$ & ( do ) & 50 & 55 & 42 \\
\hline & R-6 & ( do ) & 50 & 100 & - \\
\hline & R-8 & ( do ) & 50 & 100 & - \\
\hline & H5-318 & ( do ) & 50 & 100 & - \\
\hline & Not inoculated & & 50 & 0 & - \\
\hline \multicolumn{6}{|l|}{ Experiment III ${ }^{\mathrm{d})}$} \\
\hline Soybean & $\mathrm{R}-4$ & (New group) & 50 & 55 & 58 \\
\hline Adzuki bean & $\mathrm{R}-4$ & ( do ) & 50 & 92 & 100 \\
\hline Kidney bean & $\mathrm{R}-4$ & ( do ) & 50 & 33 & 97 \\
\hline Pea & $\mathrm{R}-4$ & ( do ) & 25 & 0 & 35 \\
\hline Potato & $\mathrm{R} \cdot 4$ & ( do ) & 9 & 0 & 0 \\
\hline Rape & $\mathrm{R}-4$ & ( do ) & 100 & 3 & 8 \\
\hline Sugarbeet & $\mathrm{R}-4$ & ( do ) & 100 & 0 & 11 \\
\hline
\end{tabular}

a) Each plant was sown in a 15-cm-diameter pot containing non-sterilized soil, and two grams of inoculum per each pot which were cultured on barley grains at $25^{\circ} \mathrm{C}$ for 10 days were mixed in the soil surface with 5 pot replications, except for 9 pots of potato. Non-sterilized nursery soil was used.

b) Experiment in a glass house kept at $20^{\circ} \mathrm{C}$. Data were collected at one month after inoculation.

c) Experiment in a glass house kept at $20^{\circ} \mathrm{C}$. Data were collected at 40 days after inoculation.

d) Experiment in a glass house during early October to November. Data were collected one month after inoculation.

symptoms were more similar to those of leaf blight of sugarbeet caused by basidiospore infection with the teleomorph of $R$. solani AG-2-2 IV ${ }^{6}$ than to those of aerial blight or web blight of soybean. A stroma or stroma-like body appeared to developed only by basidiospore infection, as reported in the case of leaf blight of sugarbeet ${ }^{6)}$ and target spot of flue-cured tobacco ${ }^{18)}$. Hymenia of a new anastomosis subgroup within AG-2 of $R$. solani have been found on the stems of soybean and wheat in fields infested with the 
Table 5. Pathogenicity of leaf spot isolates of Rhizoctonia solani to leaves of soybean ${ }^{\text {a) }}$

\begin{tabular}{cccc}
\hline \hline Isolate & No. of plants & Leaves (\%) & Disease severity ${ }^{\mathrm{b})}$ \\
\hline R-3 & 3 & 100 & 2.4 \\
R-4 & 3 & 100 & 2.5 \\
R-8 & 3 & 100 & 3.5 \\
Not inoculated & 3 & 0 & 0.0 \\
\hline
\end{tabular}

a) Experiment in moist chamber kept at 20 to $25^{\circ} \mathrm{C}$ under natural light conditions. Mycelial leaf disks $(1 \times 1-\mathrm{cm})$ cultured on autoclaved soybean leaf were inoculated in the center of each leaf. Data were collected at 4 days after inoculation.

b) Disease severity: 0 (healthy) to 5 (dead). Data were collected at 3 days after inoculation.

new foliar blight of soybean ${ }^{7}$. Therefore, the primary lesions on soybean leaves were ascribed to basidiospore infection. The infection was almost uniform within a field, suggesting an air-borne type of dissemination.

$R$. solani is a complex of various strains. The anastomosis group system is considered to be the most useful grouping method for the fungus ${ }^{13,16,20)}$. At present, 11 anastomosis groups, AG-1 through AG-10 and AG-BI, have been reported ${ }^{20}$. So far, in soybean, AG-1 IA, IB and IC, AG-2-1, AG-2-2 IIIB and IV, AG-3, AG-4, AG-5, AG-7, and unknown UNK anastomosis groups have been identified from various parts of the plant ${ }^{3,8,17,19,20,22,23)}$. Leaf spot isolates from primary and secondary lesions of soybean formed strong anastomoses with the tester isolates of AG-2-1 which are thiamine-autotrophic, whereas they seldom formed anastomoses with those of AG-2-2 and AG-BI which are thiamine-auxotrophic. The only problem is that most of the leaf spot isolates tested were auxotrophic for thiamine, except for 2 isolates which could not grow even in the presence of thiamine. These findings indicate that the leaf spot isolates in the AG-2 group can be readily distinguished from the AG-2-1 or AG-2-2 subgroup on the basis of the anastomosis frequency and thiamine requirement, suggesting that leaf spot isolates are members of a new subgroup in AG-2. Since thiamine requirement is reported to be a characteristic of the anastomosis groups rather than of the individual isolates ${ }^{13,16)}$, it has been considered to be a reliable criterion for distinguishing members of certain closely related anastomosis groups ${ }^{2,13,16)}$. Recently, five intraspecific groups (ISGs) in AG-2, ISG 2A to 2E, have been reported based on isozyme polymorphism and rDNA restriction analysis of the internal transcribed spacer (ITS) region ${ }^{5}$. However, since the separation of these ISGs is not based on host range or ecological characteristics, further pathological and ecological studies are required ${ }^{5}$. Target spot isolates of ISG 2E obtained from tobacco leaves in the USA were previously assigned to AG-2-2 and then to a newly defined subgroup related to AG-2-15). However, presently these isolates have been reassinged to AG- ${ }^{21}$. In the inoculation tests of basidiospores, leaf spot isolates from soybean was not pathogenic to tobacco leaf (Naito, unpublished) but pathogenic to soybean leaf.

The culture appearance and mycelial growth temperature of the leaf spot isolates from soybean closely resembled those of AG-2-1 rather than those of AG-2-2 IIIB and IV. Hyphal linear growth rate of the leaf spot isolates at the optimum temperature was higher than that of the isolates of AG-2-1, although the difference may be attributed to the types of isolates tested.

Leaf spot isolates were highly pathogenic to soybean, kidney bean, and adzuki bean in the Leguminosae, causing severe pre-emergence damping-off, but not pathogenic to radish and rape in the Cruciferae. On the other hand, the isolates of AG-2-1 were highly pathogenic to cruciferous plants, and the results coincided with the findings reported by other authors ${ }^{3,19,22)}$.

It is reasonable to assume that the leaf spot isolates from soybean correspond to the AG-2 group on the basis of the anastomosis frequency, because the subgroup is very different from any of the defined AG-BI and AG-8 groups which seldom formed anastomoses with the isolates of AG-216,20). So far no anastomosis subgroup that can form strong anastomoses with AG-2-1 and that is auxotrophic for thiamine has been reported. Therefore, we suggest that these isolates belong a new anastomosis subgroup 3 in AG-2 (designated as AG-2-3). The assumption that this subgroup is genetically distinct from known AG-2-1 and AG-2-2 III B and IV is supported by analyses of the restriction fragment length 
polymorphism (RFLP) of ribosomal DNA internal transcribed spacers (ITS) ${ }^{4}$.

The authors thank Dr. Ogoshi, Hokkaido University, for supplying tester isolates of the anastomosis groups of R. solani.

\section{Literature cited}

1. Atkins, J.G., Jr. and Lewis, W.D. (1954). Rhizoctonia aerial blight of soybean in Louisiana. Phytopathology $44: 215-218$.

2. Carling, D.E., Leiner, R.H. and Kebler, K.M. (1987). Characterization of a new anastomosis group (AG-9) of Rhizoctonia solani. Phytopathology 77 : 1609-1612.

3. Jones, R.K. and Belmar, S.B. (1989). Characterization and pathogenicity of Rhizoctonia spp. isolated from rice, soybean, and other crops grown in rotation with rice in Texas. Plant Dis. 73 : 1004-1010.

4. Kanematsu, S. and Naito, S. (1993). Genetic identification of Rhizoctonia solani AG-2-3 based on RFLP analysis of PCR amplified rDNA ITS. Ann. Phytopath. Soc. Japan. 59: 760 (Abstr. in Japanese).

5. Liu, Z.L. and Sinclair, J.B. (1992). Genetic diversity of Rhizoctonia solani anastomosis group 2. Phytopathology $82: 778-787$.

6. Naito, S. (1990). Ecological role of basidiospores of Thanatephorus cucumeris (Frank) Donk in the incidence of foliage blight of sugar beets in Japan. JARQ 23 : 268-275.

7. Naito, S. (1993). Field survey of fructifications of Rhizoctonia spp. on the upland crops in Tohoku District. Ann. Phytopath. Soc. Japan. 59: 760 (Abstr. in Japanese).

8. Naito, S., Djaeni, M., Anggiani, N. and Haeni, P. (1993). Soil-borne diseases and ecology of pathogens on soybean roots in Indonesia. JARQ $26: 247-253$.

9. Naito, S., Nakajima, T. and Ohtou, Y. (1992). Basidiospore infection of soybean by Thanatephorus cucumeris. Ann. Phytopath. Soc. Japan. 58 : 552 (Abstr. in Japanese).

10. Naito, S., Nakajima, T. and Ohtou, Y. (1993). Anastomosis subgroup and characteristics of isolates from diseased leaves of soybean caused by basidiospore of Rhizoctonia solani AG2. Ann. Phytopath. Soc. Japan. 59 : 284-285 (Abstr. in Japanese).

11. Naito, S., Yamaguchi, T., Sugimoto, T. and Homma, Y. (1993). A simple method for the long-time culture storage of Rhizoctonia spp. on barleys' grains. Ann. Rept. Plant Prot. North Japan 44 : 20-23 (In Japanese with English summary).

12. Ogoshi, A. (1976). Studies on the grouping of Rhizoctonia solani Kühn with hyphal anastomosis and on the perfect stages of groups. Bull. Natl. Inst. Agric. Sci. C. No. 30 : 1-63 (In Japanese with English summary).

13. Ogoshi, A. (1987). Ecology and pathogenicity of anastomosis and intraspecific groups of Rhizoctonia solani Kühn. Annu. Rev. Phytopathol. 25 : 125-143.

14. Ogoshi, A. and Ui, T. (1978). Specificity in vitamin requirement among anastomosis groups of Rhizoctonia solani Kühn. Ann. Phytopath. Soc. Japan $45: 47-53$.

15. Parmeter, J.R., Jr. and Whitney, H.S. (1970). Taxonomy and nomenclature of the imperfect state. In Rhizoctonia solani, Biology and Pathology (Parmeter, J.R., Jr. ed.), Berkeley, Los Angeles and London. pp. 7-19.

16. Rovira, A.D., Ogoshi, A. and McDonald, H.J. (1986). Characterization of isolates of Rhizoctonia solani from cereal roots in South Australia and New South Wales. Phytopathology 76: 1245-1248.

17. Sherwood, R.T. (1969). Morphology and physiology in four anastomosis groups of Thanatephorus cucumeris. Phytopathology $59:$ 1924-1929.

18. Shew, H.D. and Main, C.E. (1990). Infection and development of target spot of flue-cured tobacco caused by Thanatephorus cucumeris. Plant Dis. $74:$ 1009-1013.

19. Sinclair, J.B. and Backman, P.A. (1989). Compendium of soybean diseases. APS Press, Minnesota.

20. Sneh, B., Burpee, L. and Ogoshi, A. (1991). Identification of Rhizoctonia solani species. APS Press, Minnesota.

21. Stevens, J.J., Jones, R.K., Shew, H.D. and Carling, D.E. (1993). Characterization of populations of Rhizoctonia solani AG-3 from potato and tobacco. Phytopathology 83 : 854-858.

22. Watanabe, B. and Matsuda, A. (1966). Studies on the grouping of Rhizoctonia solani Kühn pathogenic to upland crops. Bull. App. Exp. (Plant Dis. Insect Pest) 7 : 1-131 (In Japanese with English summary).

23. Yang, S.B., Berggren, T.T. and Snow, J.P. (1990). Types of Rhizoctonia foliar blight on soybean in Louisiana. Plant Dis. 74 : 501-504. 


\section{和 文 摘 要}

内藤繁男・兼松誠司：ダイズ葉から分離した Rhizoctonia solani Kühn AG-2 内の新サブグループ 3 (AG-2-3) の諸 性質と病原性

1992 年 7 月下旬, 東北農業試験場において, 秋播きコムギ立毛時に間作したダイズに原因不明の葉腐れ症状が湟全 面 $(0.6 \mathrm{ha})$ に発生した。症状は初め直径 $1 \mathrm{~mm}$, 周囲が褐色の退緑斑点を生じ，のち多湿な気象下でその周囲に円形 のち不定形，暗緑色〜褐色病班を呈した。同様な症状が岩手，宮城，秋田県の農家畑の単作ダイズにも確認された。罹 病組織からは R. solani が高率に分離された。分離菌 66 菌株のうち 64 菌株は菌糸融合群 AG-2-1 と高い頻度 $(75 \%>)$

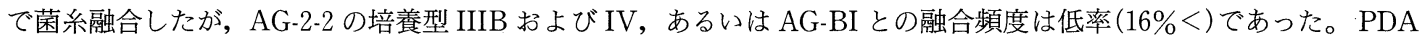
上での培養菌叢は, 初め無色のち淡褐色を呈し, 輪状に菌核を形成する傾向があった。一方, 菌系は $5 \sim 30^{\circ} \mathrm{C} て ゙$ 生育し, その最適温度は $23^{\circ} \mathrm{C}$ であった。病原性は, ダイズ，アズキ，インゲンなどに対し強く，とくに出芽前立枯れを激しく 起こし, またダイズ葉に葉腐れを生じた。ダイコン, ナタネに対する病原性は弱く, AG-2-1 の菌株が強い病原性を示 したのと対照的であった。またダイコン，コムギに対する病原性が AG-2-2 の IIIB や IV とも異なる傾向が見られた。 以上のように, ダイズ葉腐れ症状から分離した菌株の多くは, 菌糸融合頻度から AG-2 内に含まれるが, そのサブグル 一プはチアミン非要求性の AG-2-1 および要求性の AG-2-2 の IIIB・IV のいずれにも相当しない。この新しいグループ を AG-2 内のサブグループ 3 (AG2-3）と呼ぶことを提案する。 